\title{
PETROCHEMISTRY OF AN UPPER PRECAMBRIAN METASEDIMENTARY BELT IN SOUTHERN BAHIA - THE SIGNIFICANCE OF CORDIERITE
}

\author{
GIAN PAOLO SIGHINOLFI \\ Instituto de Geociencias da UFBa, Salvador, Ba. \\ CARLO GORGONI \\ Instituto di Mineralogia, Università di Modena, Italy, \\ MARINHO ALVES DA SILVA FILHO \\ Companhia de Pesquisa de Recursos Minerais, CPRM, Aracaju - Se. \\ MARIA ALBA TANNER DE OLIVEIRA \\ Instituto de Geoclencias da UFBa, Salvador, Ba.
}

Petrology and chemistry of an Upper Precambrian metasedimentary belt in Southern Bahia (Brazil) have been studied. The Belt consists essentially of muscovite-biotite gneisses and of sillimanite-grade rocks (kinzigites) containing lenses of acid-and sub-acid granulites, and pluton-like bodies of migma* titic-granitic rocks. Cordierite-bearing rocks are widely spread within the sillimanite-grade rocks. Cordierite appears always as the last paragenetic mineral and probably is formed through the

\begin{abstract}
reaction sillimanite +garnet + quartz $=$ cordierite. Chemical data indicate that the original material for mica gneisses and sillimanite-grade rocks consisted of a misture of graywackes and pelitic rocks. Comparison with modern pelagic sediments reveals low contents of metals (Fe, Mn, Ni, etc.), relatively mobile in marine environments, thus suggesting possible submarine leaching. Bulk chemistry (showing low alkali and silica contets) was found to control closely cordierite
\end{abstract}

formation which is considered related to the removal of fractions of anatectic silicate liquids. The more general significance of cordierite in metasediments is discussed stressing the role of the partial $\mathrm{H}_{2} \mathrm{O}$ pressure in the metamorphic fluids. The presence of even small amounts of $\mathrm{H}_{2} \mathrm{O}$-undersaturated melts strongly reduces the molar $\mathrm{H} 20$ fraction and favours the stabilization of cordierite. Preservation of cordierite under more hydrous conditions depends on the further development of the $P_{-} T$ metamorphic regime.

\section{INTRODUCTION}

Regional geological reconaissance and preliminary petrological and radiometric data indicate that a well-characterized metasedimentary belt of Upper Precambrian age occurs over a large area of Southern Bahia, continuing south for hundreds of kilometres essentially following the margin of the Atlan- tic ocean. In Bahia State the belt developes in a NW-SE direction, being limited to the NE by Lower Precambrian granulite facies rocks prevalent throughout the State. The contact between Lower and Upper Precambrian rocks is not exposed. Regional studies suggest a fault contact between the two forma- tions.

Structural and mineralogical features of the belt rocks indicate that they are similar to other metasedimentary rocks from other precambrian areas. The problems with wich this paper deals may, therefore, be of wider significance. 


\section{NOTES ON GENERAL GEOLOGY}

Regional geological mapping of the area covered by the Upper Precambrian sequence has been executed by wirkers of the DNPM-CPRM during the completion of the "Sul-Bahia Pro" ject". Belt rocks have been found in the Rio Pardo, Itapetinga, Monte Pascoal and Caravelas quadrangles, the total area extending in a NS direction bet. ween 15 and 18 lat. $S$ and in a E-W direction between $40^{\circ} 30^{\prime}$ and $42^{\circ}$ long. and the Atlantic margin. General geology of this area has been described by Silva (1974) and is outlined in Fig. 1. The Upper Precambrian belt consists essentiaily of two main lithotypes covering distinct areas. They are:

i) Muscuviı-biotile-oliguclase-quarız geneisses (mica gneisses) that appear 10 the N.E side of the beli. They are apparenly at the faul contact with Lower Precambrian granuliles previously siudied by one of the authors (Sighinolfi, 1970, 1971).

ii) Sillimanite-grade rocks (kinzigites). They cover a large area in Southern Bahia and extend widely to the south (Grossi Sad, 1968).

No transitional contact between the two lithotypes has been found. Near the contact areas, however, repetition of mineralogical parageneses attributable to the two rock types is sometimes visible. Banded amphibolites and calcsilicate rocks are found associated with kinzigites and especially with mica geneisses. Kinzigites present felsic bands with granitoid structure like veins, lenses or layers parallel to foliation with boudinage an pinch and swell structures.

Plutonic masses of granitic-granodioritic composition are concentrated fiwards the SW border of the beli. Migmatitic rocks and granitic pegmatites are widely scattered within the sillimanite gneisses. Granulite-facies rocks are represented by lenses of charnockites aligned in a NW-SE direction following regional patterns. The relationships with the surrounding sillimanite-bearing rocks are not clear.

Near the NE border of the Upper precambrian belt a structurally superimposed sequence of low-grade metamorphic sediments (phyllites, metaconglomerates, meta-arkoses) has been described and structurally defined by Pedreira et al. (1969) as the Rio Pardo Group.

$\mathrm{Rb}-\mathrm{Sr}$ and $\mathrm{K}-\mathrm{Ar}$ age data on the major rock units of the area were presented by Cordani (1973) and Cordani and Iyer (1978). Rb-Sr ages of the mica gneisses range between 1210 and 1490 my. with a maximum frequency at about 1.2 by. Sillimanite-grade rocks are slightly younger (about one billion years). The Rio Pardo metasediments range in age between 600 and 640 my. K-Ar data over all the units of the area give invariably ages in the range of 400 $450 \mathrm{my}$. Based on these data Cordani (1973) proposed a tectonic evolutionary scheme with the following main episodes:

1.3-1.6 by.: formation of the sedimentary basin, possibly correlated to the regional Espinaço Cycle;

0.6-0.5 by.: Brazilian orogenic cycle. Epizonal metamorphism of the Rio pardo Group. Rejuvenation of the paragneisses;

0.5-0.4 by.: End of cratonization and cooling of the Eastern Brazilian platform.

Finally, according to Leonardos and Fyfe (1974), the metasedimentary rocks of the area studied belong to a typical lıw-pressure type Allantic belı widely exiending southwards for several hundreds of kilometers.

\section{DESCRIPTIVE MINERALOGY AND PETROLOGY}

The mica gneisses are leucocratic, crudely foliated rocks which present very cumplex mineral paragenesis because of secondary reactions. Main parageneses present essentially quartz, oligoclase, non-perthitic microcline, green-brown biotite and minor amounts of muscovite and hornblende. Rutile is frequently associated with biotite. Epidote and, partially, chlorite are retrograde phases associated with the sericitization of feldespar and chloritization of biotite. Chlorite is also present as a residual mineral; it was probably involved, together with muscovite and quartz, in biotite-forming reactions as described by Bird and Fawcett (1973) and Hoscheck (1973). The frequent association of biolite and rutile suggests also a reaction of the type:

chlorite + muscovite + ilmenite $=$ biotite + rutile + $\mathrm{K}$ feldspar + quartz $+\mathrm{H}_{2} \mathrm{O}$ the last two minerals being subordinate reaction products (Ramsay, 1973).

The sillimanite-bearing geneisses are usually granoblastic and coarse-grained with porphyroblasts of cordierite and very occasionally of garnet. Constituent minerals are quartz, alkali feldspar, plagioclase, cordierite, biotite, garnet and sillimanite. The following assemblages are characteristics of the sillimanite gneisses:

i) sillimanite-biotite- $K$ feldespar

ii) sillimanite-biotite-garnet-K feldspar

\section{iii) sillimanite-biotite-cordierite}

iii) sillimanite-biotite-cordierite-garnet

Quartz and plagioclase are present in each assemblage, while graphite and magnetite are common in most. Quartz and plagioclase usually comprise more than 50 modal percent in most samples examined, although plagioclase and alkali feldspar show wide variations in their abundances depending on the mineral paragenesis. Grid-iron twinning and fine, string perthites characterize the alkali feldspar. Biotite is ubiquitous, varying from less than 1 to more than 20 per cent. It occurs as subhedral plates of variable size which are aligned with the foliation. Garnet occurs in most samples although it never exceecis 10 modal percent. It is anhedral and locally weakly elongated in the plane of foliation. Inclusions of quartz and biotite appear in some poikiloblastic grains of garnet. This, togheier wilh an apparen 1 inverse relationship between biotite and garnet abundances, suggests that the latter, at least partially, is formed by reactions wilh biolite as one of reaclanis. Cordierite is ubiquitous within sillimanitegrade rocks. It occurs as colorless, anhedral, irregulary shaped grains which vary in size from 1 to $6 \mathrm{~mm}$. They are usually poikiloblastic and contain abundant inclusions of biotite, quartz, sillimanite and rarely of garnet. Sillimanite is usually fibrolitic and intimaely assucialed with biotile. In cordierite-bearing samples it occurs also as needles within cordierite. In a few samples andalusite crystals, apparently relictic, join sillimanite.

Also a few irregulary shaped grains of staurolite found in two samples are interpreted as relicts. "Primary" muscovite associated with quartz has not been found. Fine-grained, apparently late-stage muscovite is encountered surrounding sillimanite grains. Low lemperalure alteration phenomena, which probably ocourred during retrogressive metamorphism, are also represented by the sericitic replacement of plagioclase, the marginal replacement if curdierile by pinite and the chloritization of ferromagnesian minerals. It cannot be excluded, however, that the formation of at least part of the white mica surrounding sillimanite grains might le. caused by increased $\mathrm{K}$ : $\mathrm{H}$ ratios in the fluid phase (Eugster, 1970; Kwak, 1971). Granulite-facies rocks, present in the form of small lenses within sillimanite-grade rocks, are basically formed by andesine, perthitic $K$ feldspar, quartz and orthopyroxene with limited amounts of biotite. No evidence of sillimanite, garnet or cordie- 
rite has been found in hyperstene-bearing granulites.

\section{CHEMISTRY}

Average analytical data for 17 mica gneisses, 15 cordierite-free and 18 cordierite-bearing sillimanite-grade rocks are reported in Table 1 logether with some data for amphibolite and granulitefacies rocks. The bel rocks of sedimentary origin (mica gneisses and kinzigites) show a certain range of compositional variation but most of the analyses cluster closely together around the composition of graywackes and pelitic shales (see e.g. Shaw, 1956; Pettijohn, 1963; Wedepohl, 1969; Rogers and Mckay, 1972). It can thus be assumed that the Bahia belt, like other Precambrian metasedimentary belts (e.g., Ramsay, 1973; Andreae, 1974) consists of a mixlure of varying proportions of non-mature and pelitic sediments. Diagrams A and $B$ (Fig. 2) give information on the nature of the original material. These diagrams and average bulks chemisIries (Table 1) indicate that there are not appreciable differences between mica gneisses and cordiarite-free sillimanite grade rocks. On the contrary, cordierite-bearing kinzigites present quite distinctive chemistries; they are ower in silica and alkalis with respect to cordierite-free rocks (Table 1). Figure 2 $C$ illustrates in more detail the control of chemical parameters (low ratios of alumina to mafic oxides, low alkali conten1, etc.) on the appareance of cordierile. Similar controls were found by numerous authors (Dallmeyer and Dodd, 1971; Dostal, 1975; Harriss, 1976).

Diagrams in figure 2 show that granulites have a distinctive bulk chemistry as compared to metasedimenis, clrearly depicting an igneous trend. This might suggest that granulites originally consisted of some igneous material present within the sediments but it cannot be excluded (age data are not available on these granulites) that these rocks belong to the Lower Precambrian granulitic basement.

Additional indications about the nature of original sediments can be drawn by the analysis of interelemental relationships by the use of a linear coefficient matrix. Some significative relationships $(\mathrm{r}-0.70)$ have been reported in Fig. 3, plotted after Chave and Mackenzie (1961) and Chayes (1971). Silica correlates negatively with most of the other main elements, as commonly observed in sedimentary series (Hirst and Kaye, 1971) and thus testifying to the presence of a detrital silica component. Also Ti probably was contained in detrital phases because of the lack of Ti-Al relationships, ypical of pelitic rucks (Wright, 1974). K and $\mathrm{Rb}$ are closely correlated as is conmun in a variety of geological environments. The lack of any correlation between $\mathrm{Rb}$ and $\mathrm{Al}$ may indicate that mos 1 of $\mathrm{Rb}$ was concentrated in detrital feldspar and not in the clay fraction (Stephens $e t$ al., 1975). Manganese correlates closely with iron, as in igneous rocks (Schroll, 1968). This may underline the impurtance of igneous minerals or debris within the starting materials concentrating mafic elements.

There has been much discussion recently on the contribution of submarine volcanism to the accumulation rates of some elements ( $\mathrm{Fe}, \mathrm{Mn}$, $\mathrm{Cu}, \mathrm{V}, \mathrm{Ni}, \mathrm{etc}$.) in oceans. Some studies (e.g. Bostrom and Peterson, 1969; Bosirom et al., 1973) on the composition of marine sediments where exhalative activity at the prisent time is intense (e.g. the East Pacific Rise) show that there is a gradual increase in some elements like $\mathrm{Fe}$ and $\mathrm{Mn}$, while the concentration of detrital elements like Ti falls to negligible values. On the assumption that elements like $\mathrm{Al}$ and $\mathrm{Ti}$ are tolally of continental derivation, while $\mathrm{Mn}$ and $\mathrm{Fe}$ may be in part correlated to submarine igneous activiIy, element ratios like $\mathrm{Fe} / \mathrm{Ti}$ or Äl $\mathrm{Al}+\mathrm{Fe}+\mathrm{Mn}$ (Bostrom, 1970; Bostrom et al., 1972) and $\mathrm{Fe}+\mathrm{Mn} / \mathrm{Ti}$ (Strakhov, 1976) have been used to delect whether it is, in part, of submarine exhalative origin. Calculation of these ratios for the Bahia metasediments does not reveal any enrichment of "exhalative" elements. On the contrary, these elements are depleted relative to the "detrital" elements, when compared with modern oceanic sediments. This presumably reflects the influence of different sedimentation environments, even if submarine leaching of mobile elemen Is, as proposed by Glasby (1975), cannol be excluded.

\section{OUTLINE OF METAMORPHISM}

The interpretation of the metamorfhic evolution which the belt rocks have undergone and the inference of $T, P, P H 20$ conditions during the various steps of metamorphism are hampered on one hand by the superposition of retrogressive phenomena, and on the other by the lack of compositional data on coexisting mineral phases. As the effects of relrograde metamorphism are particularly intense in mica gneisses, the following discussion will concern only sillimanite-grade rocks. A prerequisite to the general interpretation of metamorphism is the analysis of equilibria between mineral parageneses. There are many criteria to assess equilibrium conditions. The most frequently considered base on the form of grain boundaries, on the phase rule and on the composition of coexisting minerals. On account of the lack of the latter information and of the limited applicatibility of phase-rule criteria (Dallmeyer and Dodd, 1971), the analysis of phase equilibra is here mainly made by considering reciprocal phase contacts (note at this point criticisms by various authors, e.g. Loomis, 1976) Grain boundaries suggest that most of the major phases of kinzigites (biotite, sillimanite, $\mathrm{K}$ feldspar and most of garnet) represent hightemperature assemblages formed during a high-grade metamorphic episode. Cordierite is the last mineral formed during the same episode. Staurolite and andalusite represent residual reactant phases and are considered left-overs of reactions (see e.g. Yardley, 1977) which give as products the high-temperature assemblages. As regards staurolite, its rarity in the analyzed samples is probably related to its extremely limited P-T stability field (Richardson, 1968; Thompson A.B., 1976) rather than to compositional factors (Hoschek, 1969; Winkler, 1974).

The coexistance of andalusite and sillimanite in a few samples might connote univariant equilibrium. However, the relict character of andalusite strongly suggests that it is persisting metastably within the stability field of sillimanite (Albee and Chodos, 1969).

Approximate P-T estimates for the high-temperature assemblages of kinzigiles may be derived from experimentaIly and thermodinamically determined phase equilibria. The rocks are restricted to the sillimanide field, since this is the only stable $\mathrm{Al}_{2} \mathrm{Si}_{5}$ polymorph in our area (alumosilicate relations on Fig. 4 after Holdaway, 1971. Further restriction of the P-T conditions is given by the observation that muscovite and quartz are incompatible. This suggest, according 10 experimental data (Evans, 1965; hess, 1971), that, assuming intermediate (5-6) $\mathrm{Kb})$ total pressure values, the temperatures exceeded $960^{\circ}$ to $720^{\circ} \mathrm{C}$. These conditions are largely above the granite minimum for $\mathrm{PH}_{20}=\mathrm{P}$ to (Luth et al., 1964) and on account of the bulk "granitic" composition of the rocks involved extensive anatexis had to occur, assuming the fluid pressure is determinated by water pressure. The following observations seem to indicate that water undersaturated conditions 
have prevailed during the high-grade met amorphic episode:

i) the general aspect of the rocks suggests that anatexis occurred on a limited scale;

ii) graphite is still widespread and, according to Eugster and Skippen (1967), the mole fraction of water in a $\mathrm{C}-\mathrm{H}-\mathrm{O}$ fluid in equilibrium with graphite at $700^{\circ} \mathrm{C}$ or at higher temperatures is considerably less than the unity.

Reliable information on total pressure conditions can be extracted from numerous experimental data on cordierite stability at various pressures (Hirscherg and Winkler, 1968; Currie, 1971; Hensen and Green, 1970, 1971, 1973). The following schematized reactions leading to cordierite formation can account for the observed parageneses in the Bahia kinzigites:

biotite + sillimanite + quartz $=$ cordierite $+\mathrm{K}$ feldspar $+\mathrm{H} 2 \mathrm{O}$ biotite + sillimanite + quartz $=$ cordierite + garnet $+\mathrm{K}$ feldspar $+\mathrm{H} 2 \mathrm{O}$ (b) garnel + sillimanite + quartz $=$ cordierite

(c)

Obviously cordierite might form, during the same metamorphic event, by two or more reactions; being these reactions usually discontinous reactants may persist together with reaction products. Reaction $a$ might account for the observed garnet-free cordierite-bearing parageneses, as may also reaction $c$ (in the case of complete garnet breakdown). Hoffer (1976) has recently found that reaction $a$ occurs only in a very narrow P-T interval, more specifically at very low $\mathrm{P}(2.5-3 \mathrm{~Kb})$. This seems to imply that this reaction is not important in regional metamorphism. Nevertheless, reaction $a$ has been observed also in areas of regional metamorphism (e.g. Schreyer, 1966). Reaction $b$ may explain the few occurrences of cordierite-bearing rocks having garnel in the form of poikiloblastic grains including biotite and sillimanite. However, there is no clear evidence of mutual compatibility or equilibrium between garnet and cordierite. Most of the observed cordierite-bearing parageneses were probably formed by reaction $c$ which has been used, as is well known, by many researchers to calibrate the composition of coexisting garnet and cordierite as a function of temperature and pressure. Our lack of data on garnet and cordierite composition do not enable us to make more detailed deductions on the P.T metamorphic regime. The possible significance of cordierite, because of its widespread occurrence in many metasedimentary rocks, will be discussed in the next paragraph.

\section{SIGNIFICANCE OF CORDIERITE IN METASEDIMENTARY ROCKS}

The assemblage quartz-sillimanitegarnet-cordierice is common both in regionalls high-grade metasediments (Read, 19.52; Reinhardt, 1968; Hulchenl ef al. 1974) and in melasedimenis in cuntacl aureoles around granites (Lal and Moorhouse, 1969; gonzales-Bonorino, 1971; Dostal, 1975). In areas of regional metamorphism, cordierite-bearing sillimanitegrade rocks are normally intimately associated with their non-cordierite counterpart. The causes of selective occurrence of cordierite is the main problem that these rocks pose, and the complexily of this problem is evident from the commonly reported unsystematic patterns of development of cordierite. Hypotheses currently proposed (see Lal and Moorhouse, 1969) which may be pertinent to the genesis of most cordierite-bearing metasediments are:

1) Variations in the P-T metamorphic setting, total pressure being obviously the most important factor. Phenomena which may introduce such variations are essentially: a) rapid uplift of crustal segments; b) overprint of thermal events.

2) Adequate bulk-rock composition leading to the formation of cordieritebearing parageneses, the P-T metamorphic conditions being less important for the selective occurrence of cordierite. Numerous chemical parameters have been found to control the appearance of cordierite. The most important seen to be: high $\mathrm{Mg} / \mathrm{Mg}+\mathrm{Fe}$ ratios (Hensen and Green, 1971), low $\mathrm{Al} / \mathrm{Mg}+\mathrm{Fe}$ (Dallmeyer and Dodd, 1971), low lime content (Wynne-Edwards and Hay, 1963; Kays and Medaris, 1976), low alkali and silica content (Dostal, 1975; Harriss, 1976). Some of these chemical controls may be well explained by considerations on equilibria of cordierite-forming reactions with sillimanite and quartz as reactants are known to widen the stability field of cordierite (Hensen and Green, 1971). Low alkali contents and in general more mafic bulk compositions of cordierite-bearing rocks, with respect to their cordieritefree equivalents, were frequently explaneid as the result of anatectic processes with consequent loss of fractions of granitic silicate melts (Dostal, 1975; Harriss, 1976). Thus cordierite in metasediments would sometimes indicate a "restite" character of the rock. This interpretation, which may obsiously apply to the cordierite gneisses of southern Bahia, is consistent with most of the well-documented chemical features of these rocks. For example, the selective appearance of cordierite in lime-poor rocks accounts for the well-known control of plagioclase composition on the anatexis rate of granitic material. These considerations support the hypothesis the the cordierite-bearing kinzigites here studied formed under the influence of anatectic phenomena. On the other hand, anatexis in these rocks is undoubtedly documented by the numerous lit-par-lit leucosomes of granitic composition with conformable contacts.

We wan!, however, 10 stress the role of water pressure in sone cordieriteforming reactions under various fluid phase comtursitions. I thas been found (Schreycr and Seifert, 1969; Newton, 1970); Newion et al. 1974) that Mg-cordierice in dry systems is stable over wider P.T fields that in wet systems. Kays and Medaris (1976) in investigating reactions with sillimanite and biotite as reactants and garnet and for $\mathrm{PH}_{\mathrm{H} 20}=$ Ptot. However, a decrease in the $\mathrm{X}_{\mathrm{H} 20}$ mole fraction from $1 . \mathrm{O}$ to 0.5 stabilizes cordierite and garnet (Fig. 3). The supposed large differences in $\mathrm{H} 20$-conten $\mathrm{t}$ of $\mathrm{Fe}$ - and $\mathrm{Mg}$-cordierite end members (see the thermodynamic arguments by Wood, 1973, and counter arguments by Weisbrod, 1973) may also be an indication of the control of water pressure on cordierite-bearing assemblages. The most important consequence of this control is that cordierite composition and water pressure are closely intercorrelated variables. At a given T,P, PH20 set, rock composition (e.g. a given $\mathrm{Mg}-\mathrm{Fe}$ ratio) may represent a critical parameter for the appearance of cordierite. Otherwise, for any $\mathrm{P}-\mathrm{T}$ value and rock composition cordierite forms under a set of metamorphic conditions in which $\mathrm{PH}_{20}$ is critical. It has been argued (Wood, 1973) that conflicting P.T data arising from the use of the cordieritegarnet geobarometers and geothermometers (Currie, 1971, 1974; Hensen, 1972; Hensen and Green, 1970, 1971, 1973; P.H. Thompson, 1976) may only reflect the effect of variable water pressures.

In metamorphism, conditions of $\mathbf{P}_{\mathrm{H} 20}=$ Ptot might be attained essentially by:

i) dilution of the pore fluids by other fluids that reduce the activity of water, ii) selective incorporation of water in a liquid silicate phase. The first process has been proposed by Lal and Shukla (1975) and Hoefs and Touret (1975), among others. Hoefs and Touret (1975) suggest that the very low $\mathrm{H} 2 \mathrm{O}$ content of fluid inclusions in deep-seated rocks (Touret, 1970, 1971) is correlated to fluid exchange reactions with $\mathrm{CO} 2$ of mantle provenance. According to current opinions (e.g. Reverdatto et al., 
1974), however, anatexis is the most efficient process which may affect fluid phase composition during high-grade metamorphism. Many authors (Brown and Fyfe, 1972; Fyfe, 1973; Wyllie, 1977) have underlined that, because almost all the water available at depth is related to the breakdown of hydrated phases, silicate liquids produced by anatexis must be strong water-undersa" turated. If this is true, any water from residual pore fluid fractions or liberated by progressive dehidration reactions lends to be immediately captured by the melt, even if it is present in very limited amounts. This phenomena might have at least two important effects:

i) is initiale other dehydration reaclions occurring for PH2O = Plot under different P.T conditions. An example uf this chain reaction could be represented by the progressive breakdown of muscovile, biotite and hornblend;

ii) to decrease strongly the $\mathrm{H} 2 \mathrm{O}$ molar percent in the fluid phase, thus favouring the onset of cordierite-forming reactions. This will be a consequence of the greater solubylity of $\mathrm{H} 2 \mathrm{O}$ compared to that of $\mathrm{CO} 2$ and of other fluid components in silicate liquids at metamorphic temperatures (Wyllie and Tuttle, 1959).
Thus the formation of cordierite for any given rock composition would frequently coincide with stages of incipient anatexis. The commonly found "restite" character of cordierite bearing rocks in comparison to their cordieritefree counterparts suggests that the production of anatectic melt is frequently accompanied by remotion of melt fractions. This, however, does not necessarily occur and liquids may recrystallize in loco giving "granitic" mineral parageneses. If the liquid-solid system remains sufficently ciosed to water during recrystallization of liquids it should be expected an inverse reaction between liquids becaming progressively $\mathrm{H} 2 \mathrm{O}$-saturated and relatively anhydrous cordierite generated under low $\mathrm{PH} 2 \mathrm{O}$ conditions. Such a reaction would presumably lead to break-down of cordierite and this is not usually observed, cordierite persisting logether with newsly formed hydrated phases (biotite) in granitic leucosomas.

The persistence of cordierite under varying $\mathrm{PH} 2 \mathrm{O}$ conditions may be imputed to cinetic factors inherent to melamorphic reactions but, probably, may be related to the much debated rate of diffusion of water within high-grade cordierites. II is well known that high-grade cordierite may contain high $\mathrm{H} 2 \mathrm{O}$ contents independently on their bulk composition and recently Lepezin and Melinosky (1977) showed that the persistence of hydrous cordierite under conditions of high-grade metamorphism is possible only if cooling of the rocks after metamorphix climax occurs at a nearly constant Ptot.

Under these conditios, if $\mathrm{PH} 2 \mathrm{O}$ increases, early formed anhydrous cordierite may re-equilibrate to hy. drous cordierite withoul undergoig destruction. In this case final stages of regional metamorphism will be essentially related to variations in thermal regimes, for example as consequence of reduced addition, after the metamorphic climax, of heat from deep thermal sources.

\section{Acknowledgements}

Financial support for this research was provided by the Brazilian CNPq and by the "convenio" UFBa-FINEPCNPq". the authors wish to tank Prof. W.S. Fyfe and Drs. B. Kronberg and T. La Trur (UWO University, London Canadi) for the critical reading of the manuscripl and useful suggestions.

\section{Bibliografia}

ALBEE, A.L. and CHODOS, A.A. - $1969-$ Ninor element content of coexisting $\mathrm{A}_{2} \mathrm{SiO}_{5}$ polimorphs. Am. J. Sci. 267: 310-316.

ANDREAE, N. O. $-1974-$ Chemical and stable isotope composition of the high grande metamorphic rocks from the Arendal area southern Norway. Contrib. Nimeral. Petrol. 47: 299-316.

BIRD, G.W. and FAWCETT, J.J. - 1973 Stability relations of $\mathrm{Ng}$-chlorite-muscovite and quartz between 5 and $10 \mathrm{~kb}$ water pressure. J. Petrol. 14: 415-428.

BOSTRON, K. $-1970-$ Submarine volcanism as a source for iron. Earth Planet. Sci Letters 9: 348-354.

BOSTRON, K., JOENSUU, O., VALDES, S and RIERA, N. - 1972 - Geochemical hystory of South Atlantic ocean sediments since late Cretaceous. Narine Geol. 12: 85-121.

BOSTRON, K , KRAENER, $T$, and GARTNER, S. - 1973 - Provenance and accumulation rates of opaline silica, Al, Ti, Fe, $\mathrm{Nn}, \mathrm{Cu}, \mathrm{Ni}$ and $C_{0}$ in Pacific pelagic sediments. Chem. Geol. 11: 123-149.

BOSTRON, K, and PETERSON, N.N.A. 1969 - The origin of the aluminium-poor ferromanganoan sediments in areas of highe heat flow on the East Pacific Rise. Narine Geol 7: 427-447.

BROWN, G.C. and FYFE, W.S. - $1972-$ The transition from metamorphism to melting: status of the granulite and eclogite facies. Int. Geol. Congr, 24th, Sect. 2: 27-23.

CHAVE, K.E. and NACKENZIE, F.T. - 1961 - A statistical technique applied to the geochemistry of pelagic muds. J. Geol. 69: $572-582$.

CHAYES, F. - 1971 - Ratio correlation. University of Chigago Press, Chigago, I11., $99 \mathrm{pp}$. CORDANI. U.G. - 1973 - Evolução geológica pre-cambriana da faixa costeira do Brasil, entre Salvador e Vitória. Livre Docencia Thesis, University de Săo Paulo, Săo Paulo, $98 \mathrm{pp}$. CORDANI, U.G, and IYER, S.S. - 1978 Comentários sobre as determinaçes geocronológicas disponíveis na Folha Salvador. Carta do Brasil ao Nilionésimo. Folha Dalvador, SD 24, DNPM (in press).

CURRIE, K.L. - 1971 - The reaction 3 cordierite - 2 garnet $X 4$ sillimanite $X 5$ quartz, as geological thermometer in the Opinicon Lake region, Ontario, Contrib. Mineral. Petrol 33: 215-226.

CURRIE, K.L. - 1974 - A note on the calibration of the garnet-cordierite geothermometer and geobarometer. Contrib. Nineral. Pe trol. 44: 35-44.

DALLNEYER, R.D. and DODD, R.T - 1971 - Distribution and significance of cordierite in paragneisses of the Hudson highlands, southeastern New York. Con. trib. Nineral. Petrol. 33, 289-308.

DOSTAL, J. - $1975-$ The origin of garnet-cordierite-sillimanite bearing rocks from Chandos Township, Ontario. Contrib. Nineral. Petrol. 49: 163-175.

EUGSTER, H.P. - $1970-$ Thermal and ionic equilibria among muscovite, $\mathbf{K}$ felspar and aluminosilicate assemblages. Forshr. Nineral. 47: $106-123$

EUGSTER, H.P. and SKIPPEN, G.B. - $1967-$ lgneous and metamorphic reactions involving gas equilibria. In: Researches on Geochmistry P.H. Abelson (Ed.), vol, 2, New York: J. Wiley.

EVANS, B.W, - $1965-$ Application of a reaction -rate method to the breakdown equibria of muscovite plus quartz. Am. J. Sci. 263: $647-667$
FYFE, W.S - 1973 - The generation of batholiths. Tectonophysics 17: 273-283.

GLASBY, G.P. - 1975 - Geochemical dispersion patterns associated with submarine geothermal activity in the Bay of Plenty, New Zea land. Geochem. J. 9: 125-138.

GONZALES-BONORINO, F. - 1971 - Netamorphism of the crystalline basement of Central Chile. J. Petrol. 12: 149-175.

GROSSI SAD, H.G. - 1968 - Esboco geológico do Estado de Ninas Gerais, Escala 1:1.000.000 (Umpubl.)

HARRIS, N.B.W. - 1976 - The significance of garnet and cordierit from the Sioux Lookout Region of the English river gneiss belt. Northern Ontario. Contrib. Nineral. Petrol. 55: $91-104$.

HENSEN, B.3. - 1972-Cordierite-garnet equilibrium as a function of pressure-temperature and $\mathrm{Fe}-\mathrm{Ng}$ ratio. Yearbook, Carnegie Inst. Washington $71: 418-421$.

HENSEN, B.J, and GREEN, D.H. - 1970 Experimental data on coexisting cordierite and garnet under high-grade metamorphic conditions. Phys. Earth Planet. Sci. Int. 3: 431.440 .

HENSEN, B.J. and GREEN, D.H. - $1971-$ Experimental study of the stability of cordierite and garnet in pelitic compositions at high pressures and temperatures. 1. Compositions with excess aluminosilicate. Contrib. Nineral. Petrol. 33: 309-330.

LEPEZIN, G.G. and NELENEVSKY, V.N. 1977 - On the problem of water diffusion in the cordierites. Lithos 10: 49-57.

LOONIS, T.P. - 1972 - Contact metamor phism of pelitc rocks by the Ronda ultramafic intrusion, southern Spain. Geol. Soc. Am. Bull. 83: 2449-2474.

LOONIS. T.P. 1976 - Irreversible reactions 
in high-grade metapelitic rocks. J. Petrol. 17: $559-558$

LUTH, W.C., JAHNS, R.H. and TUTTLE, O.F. 'a . The granite system at pressures of 4 to 10 kilobars. J. Geophys. Res. 69: 759.773.

NEWTON, R.C. - 1970 - An experimental determination of the high pressure stability limits of magnesian cordierite under wet and dry conditions. J. Geol. 80; 398-420.

NEWTON, R.C., CHARLU, T.V, and KLEPPA, O.J. - 1974-A calorimetric investigation of the stability of anhydrous $\mathrm{Ng}$-cordierite with application toe granulite facies metamorphism. Contrib. Nineral. Petrol. 44: 295-311.

PEDREIRA, A.J., SOUTO, P.G. and AZEVEdo, H. - 1969 - Netassesimentos do Grupo Rio Pardo, Bahia-Brasil. SBG., Congr. Bras. Geol., Anais, 87-99.

PETTIJOHN, F.J. - 1963 - Chemical composition of sandstones excluding carbonate and volcanic sands. IN: N. Fleischer (Ed.), Data of Geochemistry. Geol. Surv. Profess. Papers 4405, 21 pp.

RANSAY, C.R. - 1973 - The origin of biotite in Archean meta-sediments near Yellowknife, N.W.T., Canada. Contrib. Nineral. Petrol. 42: 43-54.

RAVINDRA, K. LAL and RAVI, S. SHUKLA 1975 - Genesis of cordierite-gedrite-cummingtonite rocks of the northern portion of the Khetri Copper Belt, Rajasthan, India, Lithos 8: $175-186$

READ. H.H. - 1952 - Netamorphism and migmatization in the Ythan Valley, Aberdeenshire. Trans. Edinb. Geol. Soc. 15: 265-279.

REINHARDT, E.W. - 1968 - Phase relations in cordierite-bearing gneisses from the Gananoque area, Ontario, Can. J. Earth Sci. 5: 455-482.

REVERDATTO, VV SHARAPOV VN. LAVRENTEV, Yu. $\dot{G}$. and POKACHALOVA O.S. - 1974 - Investigations in isochemical contact metamorphism. Contrib. Nineral. Petrol. 48: 289-299.

RICHARDSON, S.W. - 1968 - Staurolite stability in a part of the system Fe-Al-Si-O-H J. Petrol. 9: 467.488 .

HENSEN, B.J, and GREEN, D.H. - 1973 - Experimental study of cordierite and garne in pelitic compositions at high pressures and temperatures. III. Synthesis of experimental data and geological applications. Contrib. Nineral. Petrol. 38: 151-166.

HESS, P.C. - 1969 - The metamorphic paragenesis of cordierite in pelitic rocks Contrib. Nineral. Petrol. 24: 191-207.

HESS, P.C. - $1971-$ Prograde and retrograde equilibria in garnet-cordierite gneisses in south-central Nassachussets. Contrib. Nineral Petrol. 30: 177-195

HIRSHERG, A. and WINKLER, H.G.F. - 1968 - Stability relations between chlorite, cordierite and almandine during metamorphism Contrib. Nineral. Petrol. 18: 17-42.

HIRST, D.N. and KAYE, N.J, - $1971-$

Factors controlling the mineralogy and chemis try of an Upper Visean sedimentary sequence from Rookhope, County Durham. Chem. Geo 8: $37-69$

HOEFS, J. and TOURET, J. - $1975-$ Fluid inclusion and carbon isotope study from Bamble granulites (South Norway). Contrib. Nineral. Petrol, 52: 16S-174.

HOFFER, E, -1976 - The reaction silimanite $X$ biotite $X$ quartz - cordierite $X$ K felspar X $\mathrm{H}_{2} \mathrm{O}$ and partial melting in the system $\mathrm{K}_{2} \mathrm{O}-\mathrm{Fe} 0 \cdot \mathrm{MgO}-\mathrm{Al}_{2} \mathrm{O}_{3}-\mathrm{SiO}_{2}-\mathrm{H}_{2} \mathrm{O}$. Contrib. $\mathrm{Mi}$ neral. Petrol, 55: $127-130$

HOLDAWAY, N.J. - 1971 - Stability of andalusite and the aluminium silicate phase diagram. Am. J. Sci. 271: 97-131

HOSCHEK. G. - 1969 - The stability of staurolite and chloritoid. Contrib. Nineral. Petrol 22: 208-232.

HOSCHEK, G. - $1973-$ Zur Stabilitat metamorpher Biotit-Paragneissen. Tschermaks Nin. Petr. Nitt. 20: $48-58$

HUTCHEON, l. FROESE, E and GORDON, T.N. - 1974 The assemblage quartzsillimanite-garnet-cordierite as an indicator of metamorphic conditions in the Daly Bay complex, NW.T. Contrib. Nineral. Petrol. 44: 29.34

KAYS, N.A, and Nedaris, L.G, - 1976 - Petrology of the Hara Lake paragneisses, Northeastern Saskatchewan, Canada. Contrib. Nineral Petrol. 59: 141-159.

KWAK, T.A.P. - 1971 - The selective replacement of the aluminium silicates by white mica. Contrib. Nineral. Petrol. 32: 193-210.

LAL, R.K. and NOORHOUSE, W.W. - $1969-$ Cordierite-gedrite rocks and associated gneisses of Fishtail Lake, Harcourt Township. Ontario, Can. J, Earth. Sci, 6: 145-165.

LEONARDOS, O.H. and FYFE, W.S. 1974 - Ultrametamorphism and melting of a continental margin: the Rio de Janeiro region Brzil. Contrib. Nineral. Petrol. 46: 201-214.

ROCHE, H. DE LA - 1965 - Sur l'xistence de plusieurs facies geochimiques dans les schistes paleozoiques des Pyrenees Luchonaises. Geol. Rdsch., Dtsch. 55: 274-301.

ROGERS, J $W$ and NcKAY, S.N - 1972 Chemical evolution of geosynclinal material. Geol. Soc. Am. Nem. 135: 3-28.

SCHREYER, W - - 1966 - Netamorpher Ubergang Saxothyringikum - Noldanubikum ostlich Tirschenreuth/obpf., nachgewiesen durch phasenpetrologiesch Analyse. Geol. Rundschau 55: $481 \cdot 509$

SCHREYER, W. and SEIFERT, F. $1969-$ Compatibility relations of the aluminium silicates in the systems NGO-AL ${ }_{2}$ $\mathrm{SiO}_{2}-\mathrm{H}_{2} \mathrm{O}$ and $\mathrm{K}_{2} \mathrm{O}-\mathrm{Al}_{2} \mathrm{O}_{3}-\mathrm{SiO}_{2} \cdot \mathrm{H}_{2} \mathrm{O}$ at high pressure. Am. J. Sci. 267A: 407.443 .

SCHROLL, E. - 1968 - Abundance of the chemical elements in the main rock types of the lithosphere in relation to a system of correlations, In: L.H. Ahrens (Ed), Origin and Distribution of the Elements. Perganon, Oxford.

SHAW, D.N. - $1956-$ Geochemistry of pelitic rocks. Part. Ill. Najor elements and general geochemistry. Bull. Geol. Soc. Am. 62 919-934.

SIGHINOLFI, G.P. - 1970 - Investigations into the deep levels of the continental crust. Petrology and chemistry of the granulite facies terrains of Bahia (Brazil). Atti Soc. Toscana Sci. Nat. Pisa, Nem., P.V., Serv, A, 77. 327-341.

SIGHINOLFI, G.P. - 1971 - Investigations into deep crustal levels: fractionating effects and geochemical trends related to high-grade metamorphism. Geochim. Cosmochim. Acta 35: 1005-1021.

SILVA, N.A. Filho - 1974 - Os kinzigitos de extremo Sul da Bahia: sua origem e posicao estratigráfica relativa. XXVIII Congr. Brasl. Geol., Porto Alegre (RGS)

STEPHENS, W.E., WATSON, S.W., PHILIP, P.R. and WEIR, J.A. - 1975 - Element associations and distributions through a lower Paleozoic graptolitic sequence in the southern uplands of Scotland. Chem. Geol. 16: 269-294

STRAKHOV, N.N. $-1976-$ Origin of increased amounts of elements in pelagic sediments of the oceans. Int. Geol. Rew. 18:306.416.

THONPSON, P.H. - 1976 - Isograd patterns and pressure-temperature distributions during regional metamorphism. Contrib. Nineral. Petrol. 57: 277.295.

THONPSON, A.B. - 1976 - Nineral reactions in pelitic rocks; 1 . Prediction of the P.T.X (fe$\mathrm{Ng}$ ) phase relations. Am. J. Sci. 276: 401-424.

TOURET, N.J. - 1970 - Le facies granulite, metamorphisme en milieu carbonique.

TOURET, J. - 1971 - Les facies granulite en Norvege meridionale. I. Les associations mineralogique. Lithos 4: 423.436 .

WEDEPOHL, K.H. - 1969 - Handbook of Geochemistry (K.H. Wedepohl Ed.), Vol. 1, Berlin, $442 \mathrm{pp}$.

WEISBROD, A. - 1973 - The problem of water in cordierite. Carnegie Inst. Washington, Yearbook 72: 521-523.

WINKLER, H.G. - $1974-$ Petrogenesis of metamorphic rocks. 4th. ed., New York. Springer-Verlag.

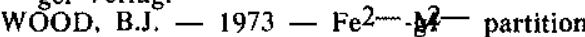
between coexisting cordierite and garnet a discussion of the experimental data. Contrib. $\mathrm{Nineral}$. 40: $253-258$

WRIGHT, P.L. - 1974 - The chemistry and mineralogy of the clay fraction of sediments from the Southern Barents sea. Chem. Geol. 13: $197-216$

WYLLIE, P.J. - 1977 - Crustal anatexis: an experimental review. Tectonophysics 43: $41-71$.

WYLLIE, P.J, and TUTTLE, O.F. - $1959-$ Effect of carbon dioxide on the melting of granite and felspar. Am. J. Sci. 257: 648-655.

WYNNE-EDWARDS, H.R and HAY, P.W 1963 - Coexisting cordierite and garnet in regionally metamorphosed rocks from the Westport area, Ontario. Canad, Niner. 7: 453.478.

YARDLEY, B.W.D. 1977 - The nature and significance of the mechanism of sillimanite growth in the Connemara schists, Ireland. Contrib. Nineral. Petrol. 65: 53-58. 

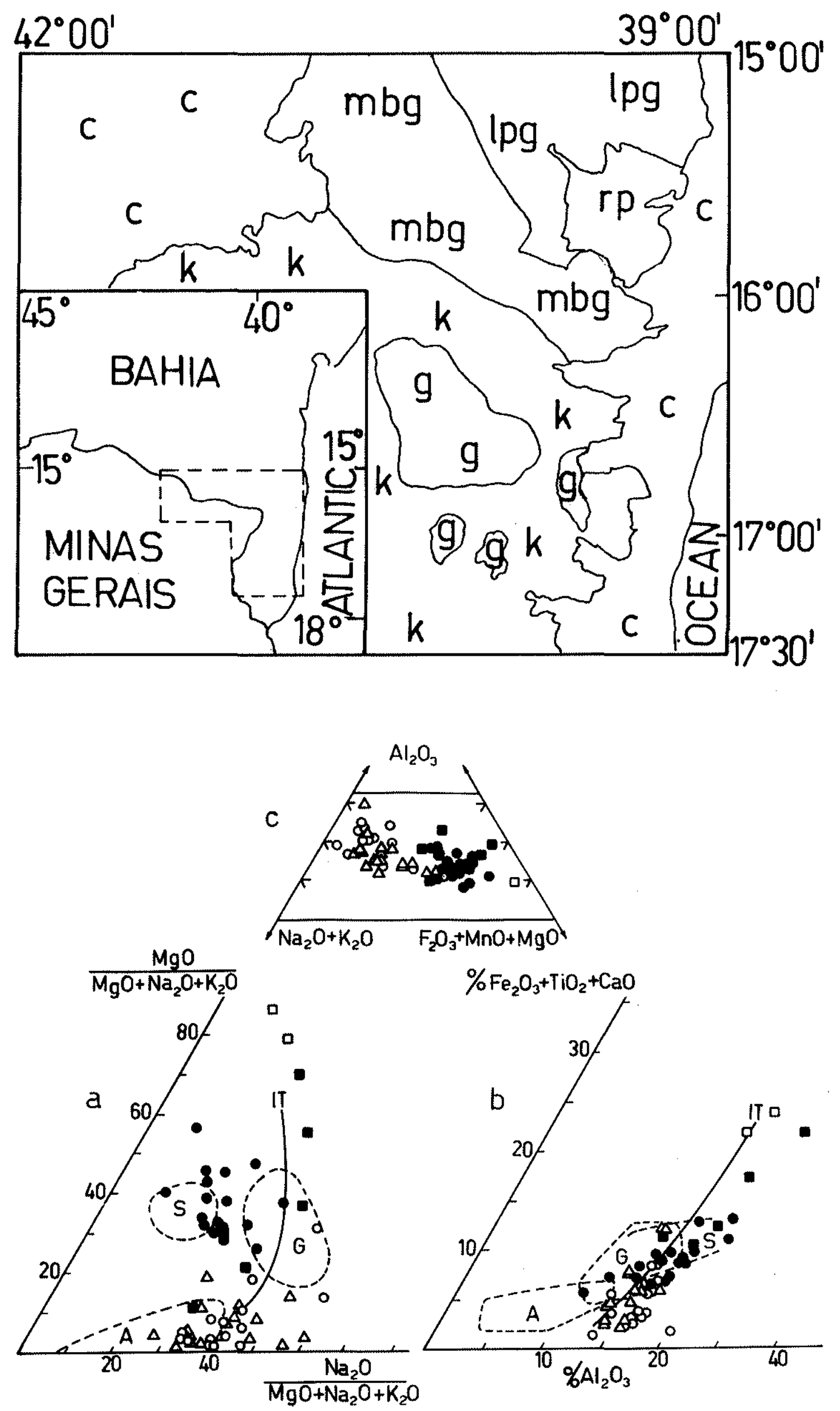

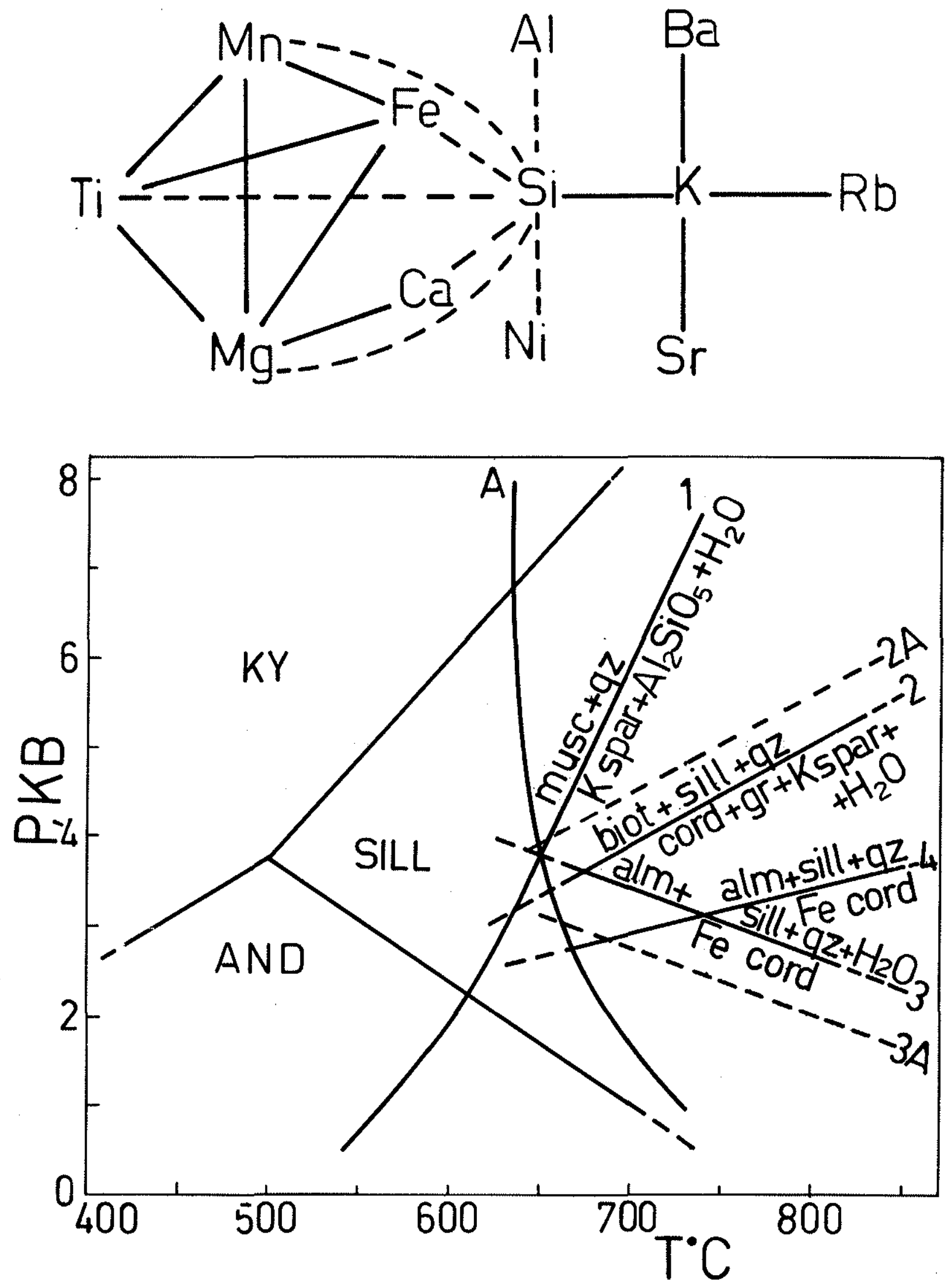


\begin{tabular}{|c|c|c|c|c|c|}
\hline \multicolumn{6}{|c|}{ Tabel. 1 Average composition of the main rock types } \\
\hline & $\begin{array}{l}\text { musco. - - biot. } \\
\text { gneiss }\end{array}$ & amphibolite & $\begin{array}{l}\text { cordierite-free } \\
\text { kinzigites }\end{array}$ & $\begin{array}{l}\text { cord. - bearing } \\
\text { kinzigites }\end{array}$ & granulites \\
\hline $\mathrm{N}^{0}$ & 17 & 2 & 15 & 18 & 5 \\
\hline $\mathrm{SiO}_{2}$ & 69.28 & 46.42 & 69.18 & 64.65 & 58.16 \\
\hline $\mathrm{TiO}_{2}$ & 0,63 & 0.92 & 0.39 & 0.79 & 0.89 \\
\hline $\mathrm{Al}_{2} \mathrm{O}_{3}$ & 15.05 & 17.87 & 16.19 & 16.58 & 18.74 \\
\hline Fe tot. + & 3.68 & 7.94 & 2.41 & 6.98 & 7.30 \\
\hline $\mathrm{MnO}$ & 0.06 & 0.20 & 0.04 & 0.14 & 0.15 \\
\hline $\mathrm{MgO}$ & 0.50 & 8.95 & 0.65 & 2.80 & 2.38 \\
\hline $\mathrm{CaO}$ & 1.76 & 13.59 & 1.65 & 1.04 & 6,51 \\
\hline $\mathrm{Na}_{2} \mathrm{O}$ & 3.47 & 1.67 & 3.54 & 1.84 & 2.30 \\
\hline $\mathrm{K}_{2} \mathrm{O}$ & 4.40 & 0.21 & 4.29 & 2.72 & 1.88 \\
\hline $\mathrm{P}_{2} \mathrm{O}_{5}$ & 0.21 & 0.05 & 0.18 & 0.17 & 0.51 \\
\hline $\mathrm{Cr} \mathrm{ppm}$ & 26 & 312 & 51 & 236 & 161 \\
\hline $\mathrm{Ni} "$ & 26 & 140 & 13.1 & 43.3 & 7.4 \\
\hline Rb " & 138.2 & 1. & 196.6 & 111.3 & 65.8 \\
\hline $\mathrm{Sr} "$ & 195 & 415 & 246 & 123 & 272 \\
\hline $\mathrm{Ba} "$ & 1067 & 210 & 899 & 622 & 552 \\
\hline $\mathrm{Zr} "$ & 788 & 83 & 508 & 411 & 506 \\
\hline
\end{tabular}

